\title{
An integrated approach to achieving campus sustainability: Assessment of the current campus environmental management practices
}

\author{
Habib Alshuwaikhat \\ Professor of Sustainable Development and Urban Planning \\ King Fahd University of Petroleum \& Minerals \\ SAUDI ARABIA \\ \& \\ Ismailia Abubakar \\ Academic Development \\ King Fahd University of Petroleum \& Minerals \\ SAUDI ARABIA
}

\section{Quotation information}

ALSHUWAIKHAT, Habib; ABUBAKAR, Ismailia (2008), "An integrated approach to: achieving campus sustainability: Assesment of the current campus environmental', management practices". Proceedings of the 4th International Barcelona Conference on: Higher Education, Vol. 7. Higher education for sustainable development. Barcelona: GUNI. Available at http://www.guni-rmies.net.

\begin{abstract}
Campus sustainability has become an issue of global concern for university policymakers and planners as result of the realization of the impacts the activities and operations of universities have on the environment. The issue has also been intensified by the pressure from government environmental protection agencies, sustainability movements, university stakeholders as well as the momentum of other forces including student activism and NGOs. In 1990, the Talloires Declaration at an international conference in France becomes the first official statement made by university administrators of a commitment to environmental sustainability in higher education. The declaration is a ten-point action plan for incorporating sustainability and environmental literacy in teaching, research, operations and outreach at colleges and universities. Over 300 university presidents and chancellors in over 40 countries
\end{abstract}




\section{Vol. 7. Higher education for sustainable development}

GUNI - Global University Network for Innovation - www.guni-rmies.net

have signed the declaration as a commitment to campus sustainability and several of them have embarked on projects and initiatives to incorporate sustainability into their systems.

A sustainable university is defined by Velazquez et al, $(2006$, p. 812) as "A higher educational institution, as a whole or as a part, that addresses, involves and promotes, on a regional or a global level, the minimization of negative environmental, economic, societal, and health effects generated in the use of their resources in order to fulfil its functions of teaching, research, outreach and partnership, and stewardship in ways to help society make the transition to sustainable lifestyles." Cole (2003, p. 30 ), also defines a sustainable campus community as "the one that acts upon its local and global responsibilities to protect and enhance the health and well being of humans and ecosystems. It actively engages the knowledge of the university community to address the ecological and social challenges that we face now and in the future". A sustainable university campus also connotes a clean and enjoyable campus environment that promotes equity and social justice having a prosperous economy through energy and resource conservation, waste reduction and efficient environmental management that benefits the present and future university community.

There is a common understanding in the literature that a sustainable university campus implies a better balance between economic, social and environmental goals in policy formulation as well as a long-term perspective about the consequences of today's campus activities. As sustainability is characterized by economic growth based on social justness and efficiency in the use of natural resources, it should includes the recognition that all stake holders' co-operation and participation is required to effectively achieve sustainability goals.

The need for environmental sustainability in university campuses needs not to be overemphasized and have been stressed in many literatures. Universities, like cities, also have complex activities and operations with potentially significant environmental impacts that, until recently, have been largely overlooked in terms of social and environmental responsibility. Many university-related activities and operations require monitoring for significant environmental impacts. These include workshops and laboratory use, buildings and grounds maintenance as well as energy and chemical use. Universities use considerable amounts of electricity, hydrocarbon 
fuels and water, each with implications for environmental quality. With regard to their consumption of energy and materials, universities can therefore be comparable to some smaller cities. With such a range of potential impacts, environmental management and sustainability at colleges and universities requires an approach similar to that of towns.

The intensified and unsustainable demand for land, water, and other resources resulting from the rapid growth of university population and the expansion of campus lead to increased degradation of its natural ecosystems and erode the life supporting systems that uphold human civilization. Caring for natural resources and promoting their sustainable use is an essential response of the world community to ensure its own survival and well being. Environmental resources sustainability is a necessary foundation for sustainable development. In the case of university, which represents the combined actions of its inhabitants, the use of an effective sustainability tool would imply some additional environmental respect within the economic relationships of this area.

Universities also make a significant contribution to the development of our society, and therefore have a special societal responsibility, in particular with regard to the sustainable protection of the environment and the use of resources. Also, demonstrating more sustainable practices on campus will provide a model for alumni to take initiative elsewhere. Therefore, universities should promote a pattern of development that would be compatible with a safe environment, biodiversity, ecological balance, and intergenerational equity. As sustainability concept is applied to universities, it should serve as a means of configuring the campus and its various activities so that the university, its members and its economies are able to meet their needs and express their greatest potential in the present and in a the long term.

There are several practices and initiatives adopted by universities in promoting sustainability in campuses, which are based on the university management's notion of the concept of sustainability and the university environmental goals and targets. Some universities' concept of a sustainable university is having a master plan, environmental plan, environmental guidelines or environmental statement. Other universities employ ISO 14001 EMS, Green campus initiative, Environmental Impact Assessment of projects, environmental stewardship, etc., as a means of achieving 
campus sustainability.

Environmental issues are now more complex and interconnected and environmental sustainability by its very nature requires an integrated and systematic approach to decisions making, investments and management. Therefore, there is need for a professional and systematic environmental management approach to reducing the consumption of resources and negative impacts of the various campus operations and promoting campus sustainability. Unfortunately, this approach is generally lacking in most universities, and hence achievement of sustainability becomes difficult.

Therefore, this paper proposes an integrated approach to achieving university campus sustainability. The paper shades more light on the concept of sustainability and why university campuses need to be sustainable. Then the widely used practices for achieving campus environmental sustainability are highlighted. The framework of the integrated approach, its strategies and advantages in promoting campus sustainability are then discussed. The study then presents some considerations for university administrators, urban planners and policy makers in promoting campus sustainability and some conclusions are finally drawn.

\section{The complete paper is not available.}

